Original Research Article

\title{
Study of drug utilization trends in respiratory tract infections in a tertiary care teaching hospital: a retrospective study
}

\author{
Avula Naveen ${ }^{1}$, M. R. Sravani ${ }^{2 *}$
}

${ }^{1}$ Department of Pharmacology, GIMSR, Gitam University, Visakhapatnam, Andhrapradesh, India

${ }^{2}$ Department of Pharmacology, Vishwa Bharathi Medical College, Kurnool, Andhrapradesh, India

Received: 16 September 2017 Accepted: 22 September 2017

*Correspondence to:

Dr. M. R. Sravani,

Email: raghavasravani@ yahoo.com

Copyright: (C) the author(s), publisher and licensee Medip Academy. This is an openaccess article distributed under the terms of the Creative Commons Attribution NonCommercial License, which permits unrestricted noncommercial use, distribution, and reproduction in any medium, provided the original work is properly cited.

\begin{abstract}
Background: Drug utilization studies play crucial role in the health sector and ultimately it provides insight into the efficiency of drug use and results of such research can be used to help to set priorities for the rational use of medicines and allocation of health care budgets. Respiratory tract infections (RTIs) contributing to significant mortality and morbidity of populations especially in developing countries like India. Polypharmacy and irrational prescription are significant negative fallouts in treatment of RTIs. Keeping in view of this, our study was undertaken to analyze the drug utilization pattern of RTIs.

Methods: The study was conducted at Gandhi Hospital, after obtaining permission from the Institutional Ethics Committee. We have collected data of 600 case records of the patients diagnosed with respiratory tract infection and evaluated for prescribing patterns in consonance with WHO indicators.

Results: Out of the total case records $348(58 \%)$ were of male patients and 252 $(42 \%)$ of female patients. Age wise distribution was done; 79 (13.16\%) 0-15 years, $46(7.67 \%)$ 16-30 years, $123(20.50 \%)$ 31-45 years, $194(32.33 \%)$ 46-60 years and $158(26.33 \%)$ patients belongs to $>60$ years of age group respectively. A total of 4682 drugs were prescribed, 2468 (52.71\%) antibiotics, $768(16.4 \%)$ bronchodilators, $581(12.4 \%)$ corticosteroids, $323(6.89 \%)$ antacids, 542 $(11.57 \%)$ in miscellaneous category respectively. With regard to formulations $2463(52.60 \%)$ oral, $1463(31.24 \%)$ injectable and $756(16.14 \%)$ inhalational drugs were prescribed. Numbers of Fixed dose combinations were 712 (15.20\%). 7.8 drugs were prescribed per prescription. 2493 (53.24\%) drugs were prescribed from National Essential Medicine List. 4168 (89.02\%) drugs were prescribed by their brand names.

Conclusions: Prescription of drugs with branded names, Irrational prescribing, poly pharmacy were observed in our study. So there is an urgent need for creating awareness among the health care professionals regarding rational prescription by using data from from drug utilization studies.
\end{abstract}

Keywords: Drug utilization studies, Respiratory tract infections, Rational prescription

\section{INTRODUCTION}

Drug utilization study defined as marketing, distribution, prescription, and use of drugs in a society, with special emphasis on the resulting medical, social and economic consequences. ${ }^{1}$ It plays crucial role in the health sector as it deals with the patterns of prescription, quality, determinants and outcomes of usage of drugs. Ultimately it provides insight into the efficiency of drug use and results of such research can be used to help to set priorities for the rational allocation of health care budgets.

Infections of the upper and lower respiratory tract are a major cause of morbidity and mortality particularly in patients at the extremes of age, and those with pre-existing lung disease or immune suppression. ${ }^{2}$ In India, acute respiratory tract infections (ARTI) are responsible for one million deaths. Out of these $10-15 \%$ is due to acute lower 
respiratory tract infections (ALRTIs). The RTIs includes Upper respiratory tract infection (URTI), it is a nonspecific term used to describe acute infections such as common cold, pharyngitis, sinusitis, and tracheobronchitis.

Lower respiratory tract infections (LRTIs) are frequent and include community acquired pneumonia, exacerbations of chronic bronchitis, acute bronchitis, and viral lower respiratory tract infections. ${ }^{3}$ LRTIs is one of the major reasons for antibiotic treatment and because changes in antibiotic resistance patterns are a threat to its effective treatment, there is increasing concern about antibiotic prescription in the community. ${ }^{4}$

In India, we do not have adequate data on the lower respiratory tract pathogens, their resistance patterns and proper guidelines for rational use of antibiotics. ${ }^{5}$ At this juncture Drug utilization studies provide good opportunity to generate data on the aforementioned issues. Increase in prescription of antibiotics in the clinical practice even for the mild cases, selling of antibiotics over the counter without prescription by the pharmacies, poor patient compliance or non compliance with medicines further enhanced the development of antibiotic resistance.

The study of prescribing patterns is a part of medical audit and seeks to monitor, evaluate and if necessary, suggest modifications in prescribing practices to make medical care rational. ${ }^{6}$ Antibiotics are being prescribed for either prophylactic or therapeutic reasons. Irrational prescription of antibiotics might lead to drug resistance. By considering the above facts our study will be used as a tool to assess the rational prescribing pattern in our tertiary care teaching hospital.

\section{METHODS}

This project is a retrospective, non interventional and observational study. The study was conducted at Gandhi Hospital, Secunderabad, Telangana during October 2014 to February 2015 after obtaining permission from the Institutional Ethics Committee. We have collected data of 600 case records of the patients diagnosed with respiratory tract infection after getting the permission from officer of medical record department.

\section{Inclusion criteria}

Only those case records of the patients admitted with Respiratory Tract Infections (RTIs) were included in the study.

\section{Exclusion criteria}

Case records of patients diagnosed with non RTIs and other diseases and prescriptions of outpatients were excluded from the study.

The selected case records were evaluated for prescribing patterns in consonance with the WHO indicators and other parameters like Age wise distribution of diseases and incidence. The WHO indicators are average number of drugs per encounter, percentage of drugs prescribed by generic names, number of fixed dose combinations, percentage of drugs prescribed from Essential Medicine List and different drug formulations etc. All the case records were analyzed accordingly and results were tabulated by using simple statistical measures like percentages, averages, divisions and multiplications.

\section{RESULTS}

We collected and observed a total of 600 case records of patients diagnosed with respiratory tract infections from the hospital. Analyzed these case records in consonance with the WHO prescribing indicators. Our final interpretations from the study are as follows.

Out of total number of case records $348(58 \%)$ patients were male and $252(42 \%)$ were female, the most commonly affected age group of patients from our study:46-60years age group (Table 1).

Table 1: Age wise distribution of patients with RTIs.

\begin{tabular}{|c|c|c|c|c|}
\hline Male & Female & $\begin{array}{l}\text { Age in } \\
\text { years }\end{array}$ & $\begin{array}{l}\text { No. of } \\
\text { patients }\end{array}$ & Percentage \\
\hline 348 & 252 & $1-15$ years & 79 & 13.16 \\
\hline \multirow{4}{*}{$58 \%$} & \multirow{4}{*}{$42 \%$} & 16-30years & 46 & 7.67 \\
\hline & & $\begin{array}{l}31-45 \\
\text { years }\end{array}$ & 123 & 20.5 \\
\hline & & 46-60 years & 194 & 32.33 \\
\hline & & $\begin{array}{l}\text { above } 60 \\
\text { years }\end{array}$ & 158 & 26.33 \\
\hline
\end{tabular}

The respiratory tract infections prevalence, 218 (36.33\%) patients were diagnosed as chronic obstructive pulmonary disease (COPD), 152 (25.33\%) pneumonia, 112 (18.67\%) pulmonary tuberculosis, $76(12.67 \%)$ bronchial asthma, and $42(7.00 \%)$ of upper respiratory tract infection (URTI) respectively (Table 2 ).

Table 2: Respiratory Tract Infections (RTIs) prevalence.

\begin{tabular}{|lll|}
\hline RTIs & No. of patients & $\%$ \\
\hline COPD & 218 & 36.33 \\
\hline Pneumonia & 152 & 25.33 \\
\hline PTB & 112 & 18.67 \\
\hline BA & 76 & 12.67 \\
\hline URTIs & 42 & 7 \\
\hline
\end{tabular}

RTIs-Respiratory tract infections, COPD-chronic obstructive pulmonary disease, PTB-pulmonary tuberculosis, BA-Brochial Asthma, URTIs- Upper Respiratory Tract Infections.

Our study observed that a total of 4682 drugs were prescribed, out of the total $2468(52.71 \%)$ antibiotics, 768 (16.40\%) bronchodilators, $581(12.40 \%)$ corticosteroids, 
$323(6.89 \%)$ antacids and $542(11.57 \%)$ from the miscellaneous category (Table 3 ).

Table 3: Pattern of drug prescription in RTIs.

\begin{tabular}{|lll|}
\hline Drug & $\begin{array}{l}\text { Number of drugs } \\
\text { prescribed }\end{array}$ & $\%$ \\
\hline Antibiotics & 2468 & 52.71 \\
\hline Bronchodilators & 768 & 16.4 \\
\hline Corticosteroids & 581 & 12.4 \\
\hline Antacids & 323 & 6.89 \\
\hline $\begin{array}{l}\text { Other miscellaneous } \\
\text { drugs }\end{array}$ & 542 & 11.57 \\
\hline
\end{tabular}

The most commonly prescribed Corticosteroid was Prednisolone 519(89.32\%), and Antibiotics were Cephalosporins 637 (25.81\%) Levofloxacin 498 (20.17\%), Piperacillin plus tazobactam 468(18.96\%), Amoxicillin plus clavulanic acid $567(22.97 \%)$ and Ofloxacin 298 $(12.07 \%)$ respectively (Table 4$)$.

\section{Table 4: Most frequently prescribed antibiotics} in RTIs.

\begin{tabular}{|lcc|}
\hline Antibiotic & No. $(\%)$ & Percentage \\
\hline Cephalosporins & 637 & 25.81 \\
\hline $\begin{array}{l}\text { Amoxicillin + clavulanic } \\
\text { acid }\end{array}$ & 567 & 22.97 \\
\hline Levofloxacin & 498 & 20.17 \\
\hline Piperacillin + tazobactam & 468 & 18.96 \\
\hline Ofloxacin & 298 & 12.07 \\
\hline
\end{tabular}

Table 5: Different drug formulations prescribed.

\begin{tabular}{|lcllll|}
\hline $\begin{array}{l}\text { Oral } \\
\text { formulations }\end{array}$ & \multicolumn{2}{l}{$\begin{array}{l}\text { Injectable for } \\
\text { mulations }\end{array}$} & \multicolumn{2}{l|}{$\begin{array}{l}\text { Inhalational for } \\
\text { mutations }\end{array}$} \\
\hline $\begin{array}{l}\text { No. of } \\
\text { drugs }\end{array}$ & $\%$ & $\begin{array}{l}\text { No. of } \\
\text { drugs }\end{array}$ & $\%$ & $\begin{array}{l}\text { No. of } \\
\text { drugs }\end{array}$ & $\%$ \\
\hline 2463 & 52.60 & 1463 & 31.24 & 756 & 16.14 \\
\hline
\end{tabular}

Table 6: Other drug utilization parameters.

\begin{tabular}{|llc|}
\hline $\begin{array}{l}\text { Drug utilization } \\
\text { parameter }\end{array}$ & No. $(\%)$ & Percentage \\
\hline Fixed dose combinations & 712 & 15.20 \\
\hline Drugs per prescription & 7.8 & \\
\hline $\begin{array}{l}\text { Drugs from National } \\
\begin{array}{l}\text { Essential Medicine List } \\
\text { (NEML) }\end{array}\end{array}$ & 2493 & 53.24 \\
\hline $\begin{array}{l}\text { Drugs prescribed by } \\
\text { brand names }\end{array}$ & 4168 & 89.02 \\
\hline
\end{tabular}

Drug formulations prescribed, $2463(52.60 \%)$ oral, 1463 (31.24\%) injectables and $756(16.14 \%)$ inhalational (Table 5). With regard to other prescribing indicators 712 (15.20\%) fixed dose combination was prescribed, 7.8 drugs were prescribed per case record, 2493 (53.24\%) drugs were from the National Essential List of Medicine and $4168(89.02 \%)$ drugs were prescribed by brand names (Table 6).

\section{DISCUSSION}

Drug utilization studies are essential part of pharmacoepidemiological studies which provide a proper understanding usage pattern of drugs, quality and efficiency use of drugs and its outcomes. ${ }^{7}$ These studies can play a key role in helping the healthcare system to understand, interpret and improve the prescribing administration and to maintain the rational use of drugs which assist the physician's prescribing attitude in accordance with the predetermined standards by allocating them with the feed-back and also in designing, conducting and imparting educational programmes for healthcare providers. ${ }^{8}$ These studies should become a method of increasing job satisfaction and means of education for health professionals, rather than being perceived as threat or another bureaucratic burden. ${ }^{9}$

In present study, the most common diseases were chronic obstructive pulmonary disease (COPD), Pneumonia, Pulmonary tuberculosis, Bronchial asthma, and upper respiratory tract infections (URTIs), which is almost similar to the previous studies. ${ }^{10}$ The most commonly affected patients age group was 46-60 years group.

The antibiotics were most commonly prescribed drugs in treatment of RTIs which is in accordance with the other previous studies. ${ }^{11}$ In the present study, the most commonly prescribed antibiotics were cephalosporins which is in line with the study by Errabelly $\mathrm{P}$ et al. ${ }^{12} \mathrm{In}$ present study $52.60 \%$ oral, $31.24 \%$ injectables and $16.14 \%$ inhalational formulation of drugs were prescribed, while in another study $86 \%$ drugs were prescribed by oral and $14 \%$ by nasal route. ${ }^{13}$

Number of drugs per prescription were 7.8, which is in contrast to the study by Gogoi $\mathrm{S}$ et al, where average number of drugs per prescription was $6.92 .{ }^{14}$ In the present study 2493 (53.24\%) drugs were prescribed from national essential list of medicines and 4168 (89.02\%) drugs were prescribed by brand name, which is in accordance with the study by Mungrue $\mathrm{K}$ et al, where all the drugs were prescribed by brand names. ${ }^{15}$

Prescribing drugs by brand names may undermine some of the goals of Essential Medicine concept. Prescribing by generic name helps the hospital pharmacy to have a better inventory control and are often more economical than the branded ones. Regarding the prescribing of FDCs, Potential advantages of FDC's include reduced side effects, increased patient compliance, synergy and increased efficacy and reduced cost, potential disadvantages include inflexible fixed dose ratio, incompatible pharmacokinetics, increased toxicity, physician and pharmacist's ignorance. 
At the study site, the prescribers are not having any standard antibiotic prescribing guidelines for the treatment of RTIs nor are they following any standard guidelines available. Hence there is an urgent need of educational programmes in order to bring rational use of antibiotics that requires development of standard guidelines for antibiotic prescription.

\section{ACKNOWLEDGEMENTS}

Authors would like to express their gratitude to the Departments of Pulmonary Medicine and General Medicine of Gandhi Hospital for their cooperation and their scientific inputs throughout the study. I also would like to thank my colleagues Dr. Sravani, Swecha, Vijay for their contribution in Data Collection.

\section{Funding: No funding sources}

Conflict of interest: None declared

Ethical approval: The study was approved by the Institutional Ethics Committee

\section{REFERENCES}

1. Shimpi RD, Salunkhe PS, Bavaskar SR, Laddha GP, Kalam A, Patel AK. Drug utilization evaluation and prescription monitoring in asthmatic patients, Int. J. Pharm. Bio. Sci. 2012;2(1):117-12.

2. Walker BR, Colledge NR, Ralston SR, Penman ID. Davidsons Principles and Practice of Medicine, Chapter 19, Respiratory disease, $22^{\text {nd }}$ Edition. 703.

3. Mohan H. The Respiratory system. Text book of Pathology, $4^{\text {th }}$ Ed. New Delhi: Jaypee Brothers Medical Publishers (Pvt) ltd. 2000:438-439.

4. Huchon G, Gialdroni-Grassi G, Leophonte P, Manresa F, Schaberg T, Woodhead M. Initial antibiotic therapy for lower respiratory tract infection in the community: a European survey. European Respiratory Journal. 1996;9(8):1590-5.

5. Khan IA, Shobha Rani RH, Subramanyam G. Efficacy and safety of azithromycin with various cephalosporins used in treatment of lower respiratory tract infection. Indian J Pharm Pract. 2009;1(2):53-61.

6. Gujar A, Tiwari P. Antimicrobial drug use in hospitalized children. CRIPS. 2008;9(1):2-6.
7. Shimpi RD, Salunkhe PS, Bavaskar SR, Laddha GP, Kalam A, Patel KA. Drug utilization evaluation and prescription monitoring in asthmatic patients. Int. J. Pharm. Bio. Sci. 2012;2(1):117-22.

8. Varkey S, Sen S. Prescribing patterns of corticosteroids in Pulmonology Department. IJPTP. 2012;3:334-37.

9. Nandimath MK, Ahuja S. Drug Prescribing Pattern In Upper Respiratory Tract Infection In Children Aged 1-14 Years. International Journal of Pharma and Bio Sciences . 2012;3(1):299-308.

10. Mahajan HM, Date AP, Badwaik RT, Borkar AS, Wanmali SS, Gohad GV. Analysis of pattern of antimicrobial use in RTIs in a tertiary care hospital of central india-A drug utilization study. J Cont Med A Dent. 2014;2(3):59-64.

11. Pandit PR, Kokanii V, Bhave KA. Prescribing pattern of antimicrobials used for the treatment of acute respiratory tract infections in children. IJARSAT. 2016;18(1):171-5.

12. Errabelly P, Ramavath V, Afreen A, Sanaboina A. Analysis of the prescribing pattern of antibiotics in respiratory tract infections at department of medicine at a tertiary care teaching hospital. IJPSR. 2015;6(7):2693-97.

13. Tiwari P, Ahlawat R, Gupta G. Prescription patients of upper respiratory tract infection at a pediatric outpatient clinic in Punjab. Indian $\mathrm{J}$ Pharm Pract. 2014;7(2):26-32.

14. Gogoi S, Saikia PP. A study on prescribing pattern of antibiotics for upper respiratory tract infections by general practitioners in rural areas of Assam. IJSR. 2015;4(5):60-2.

15. Mungrue K, Brown T, Hayes I Ramroop S, Thurston $P$, Pereira LP. Drugs in upper respiratory tract infections in pediatric patients in north Trinidad. Pharm Pract. 2009;7(1):29-33.

Cite this article as: Avula N, Sravani MR. Study of drug utilization trends in respiratory tract infections in a tertiary care teaching hospital: a retrospective study. Int J Basic Clin Pharmacol 2017;6:2583-6. 